\title{
Complex use of mineral raw materials: formation of organizational and economic mechanism
}

\author{
V.M. Solovyova, A.A .Ilinova \\ Department of Economics, Organization and Management, Saint-Petersburg Mining University, \\ Russia
}

\begin{abstract}
To date, issues related to the effective exploitation of the resource potential are becoming in-creasingly important for Russia. Gradual depletion of the mineral and raw material base and high level of ecological risks make this issue particularly relevant in the current conditions. The study deals with the development of organizational and economic mechanism that ensures the involvement and complex use of multicomponent ores to provide domestic industrial branches with important types of mineral raw materials. The theoretical aspects and main di-rections of the complex use of mineral raw materials are discussed. Critical analysis of modern frameworks is provided, key problems and barriers both economic and managerial (legal and regulatory policy) are identified. The possible measures to improve the CUMR projects' economic efficiency are examined. The scheme of organizational and economic mechanism is presented. The study makes a number of recommendations aimed at the development of the complex use of mineral raw materials direction in Russia.
\end{abstract}

\section{Introduction}

Mineral raw materials are the main sources for the development of industrial and energy com-plex, agriculture and other national significant branches, which efficiency depends on the re-source availability. These very elements continue to be a basis for the production of more than $90 \%$ of heavy industrial products. Therefore, issues related to the rational use of mineral re-sources are becoming particularly relevant for Russia. One of them is the problem of complex use of mineral raw materials (CUMR). Gradual depletion of the mineral and raw material base, a growth of ecological risks, slow rates of the resource potential reproduction are supposed to be the reason for the increasing relevance of this matter.

The development of integrated systems and effective mining processing technologies are pointed out as key priorities within the «Rational environmental management» direction of the «Scientific and technological forecast of the Russian Federation development till 2030». How-ever, the CUMR index in Russia remains low. Deposits' exploitation is often extensive and characterized by selective mining processes.

At present, a number of managerial issues inhibited the effective development of the 
CUMR direction have been emerged. Moreover, there is a lack of economic incentive system that al-lows to attract potential subsoil users to the multicomponent ores and technogenic objects' complex exploitation. To overcome existing difficulties and to enhance the level of the CUMR in Russia it is necessary both to analyze current matters related to this issue and to offer the concept of organizational and economic mechanism.

\section{Literature review}

A large and growing body of foreign literature has discussed the importance of the environmental management as «green economy» principals are becoming more essential [1-4]. Nowadays these principles are shared by a majority of countries that stresses out the increasing relevance of ecological aspects and the importance of rational use of mineral resources at the global level $[5,6]$.

For Russia ecological aspects are particularly important as the countries' economy still has raw materials orientation. Recently the national academic literature has revealed the novel paradigm of the rational use of the resource potential based on the CUMR principles as key one [7-13]. That is why nowadays there is a large number of published studies describing the role of complex use of mineral raw materials for Russia [14-19].

Despite the significance of the CUMR for the country, scientists are not so confident about actual prospects for this direction's development. Numerous studies have attempted to identify and explain key problems and barriers of the CUMR's implementation in Russia - ineffectiveness of the CUMR projects, imperfection of the state regulation, a lack of required incentives and others [20,21].

Numerous studies have attempted to analyze the economic aspects of the complex use of mineral raw materials in the context of existing approaches to the economic evaluation [22-26]. Several studies have investigated organizational aspects of the CUMR direction's implementation. They include tax regulations [27-29], legal regimes [30], stimulating measures [23,31]. The measures discussed might be effective to overcome existing barriers. But there are no complete frameworks. The improvement of separate parts of economic and organizational mechanisms will lead to the fragmentary of the CUMR direction development.

Therefore, despite the range of existing papers related to different aspects of complex use of mineral raw materials, there are no publications devoted to economic and organizational framework's formation in order to enhance this direction in Russia. It is still not clear, how to develop this direction, what kind of measures should be realized and which mechanisms might be effective. This makes relevant the investigation offered.

\section{Methodology and design of the study}

The methodology of this study includes case studies in order to observe the current conditions of complex use of mineral raw materials in Russia, the decomposition method to identify main directions of the CUMR and to highlight existing problems, system-oriented analysis to establish recommendations aimed to the CUMR development at each stage (strategic planning and forecasting, organization, control stage). The content-analysis for the academic literature on the topic has been used. In order to identify the possibilities of applying support mechanisms and to assess their effectiveness, the investment projects' economical evaluation methods have been applied. To compare different options of the projects' implementation such indicators as net present value (NPV), internal rate of return (IRR), profitability index (PP) and payback period (PP) have been used. The methods 
collectively applied in the study made it possible to ensure the reliability and validity of the conclusions.

The legal basis of the study is formed by analyzing the Federal Law «On Subsoil», the «Strategy of development of mineral resources base of the Russian Federation till 2035», the «Scientific and technological forecast of the Russian Federation development till 2030», et al.

Paper is organized as follows: first, the general aspects of the CUMR direction are discussed. Second, the critical analysis' results of economic and organizational issues of the complex use of mineral raw materials in Russia are presented. Third, the concept of economic and organizational mechanism is offered and then discussed.

\section{Results}

The effective exploitation of the resource potential requires a paradigm shift from the excessive path to the intensive one. This implies follow-up to «green economy» and environmental principals, including the necessity of the complex use of mineral raw materials ensurance[32,33].

According to contemporary interpretation, complex use of mineral raw materials (CUMR) is most complete and cost-effective involvement of all resource components in the production process with a purpose to process mineral raw materials in valuable components [8]. All non-ferrous metal ores are complex as they contain two or more associated elements which value is sometimes higher than the value of main minerals. The qualitative indicator of the increase in the degree of complex use of resources is the approximation of the obtained product range to the processed raw materials mineralogical composition [14].

The revision of the industrial and economic significance of certain associated components might be carried out by changing market conditions (changes in the volume of demand for certain types of mineral raw materials, an increase in the level of prices, etc.) and the development of effective processing technologies that expand new opportunities in recovery of valuable components with an acceptable level of profitability [24].

To issues which are related to the complex use of mineral raw materials turn both operating enterprises and the greenfield stage companies. In general, the CUMR can be divided into three main directions varying in the level of complicity and key purposes table 1 .

Table 1. Main directions of the CUMR.

\begin{tabular}{|c|c|c|c|}
\hline Criteria & \multicolumn{3}{|c|}{ Complex use of mineral raw materials } \\
\hline Direction & Field under development & $\begin{array}{l}\text { Novel deposit (greenfield } \\
\text { stage) }\end{array}$ & Technogenic deposit \\
\hline $\begin{array}{l}\text { Main } \\
\text { characteristics }\end{array}$ & $\begin{array}{l}\text { extraction of novel } \\
\text { associated components } \\
\text { of multicomponent ores }\end{array}$ & $\begin{array}{l}\text { exploitation of the } \\
\text { Unallocated Subsoil Fund } \\
\text { deposits within principals of } \\
\text { complex use of mineral raw } \\
\text { materials }\end{array}$ & $\begin{array}{l}\text { complex processing of } \\
\text { mining wastes }\end{array}$ \\
\hline Key purposes & $\begin{array}{l}\text { expansion of the range } \\
\text { of products; gaining } \\
\text { competitive advantages; } \\
\text { access to new markets; } \\
\text { sustainability }\end{array}$ & $\begin{array}{l}\text { providing domestic industry } \\
\text { with scarce types of mineral } \\
\text { raw materials; integrated } \\
\text { development of } \\
\text { multicomponent ores; } \\
\text { implementation of new } \\
\text { projects based on the }\end{array}$ & $\begin{array}{l}\text { reduction of } \\
\text { environmental risks; } \\
\text { tailings reclamation; } \\
\text { processing of } \\
\text { accumulated waste; the } \\
\text { possibility of increasing } \\
\text { the availability of raw }\end{array}$ \\
\hline
\end{tabular}




\begin{tabular}{llll}
\hline \multicolumn{1}{c}{ Criteria } & \multicolumn{3}{c}{ Complex use of mineral raw materials } \\
\hline Direction & Field under development & $\begin{array}{l}\text { Novel deposit (greenfield } \\
\text { stage) }\end{array}$ & Technogenic deposit \\
\hline $\begin{array}{l}\text { Main } \\
\text { characteristics }\end{array}$ & $\begin{array}{l}\text { extraction of novel } \\
\text { associated components } \\
\text { of multicomponent ores }\end{array}$ & $\begin{array}{l}\text { exploitation of the } \\
\text { Unallocated Subsoil Fund } \\
\text { deposits within principals of } \\
\text { complex use of mineral raw } \\
\text { materials }\end{array}$ & $\begin{array}{l}\text { complex processing of } \\
\text { mining wastes }\end{array}$ \\
\hline introduction of innovative \\
CUMR technologies & materials \\
\hline $\begin{array}{l}\text { Search works } \\
\text { nnfrastructure }\end{array}$ & not required & required & not required \\
\hline $\begin{array}{l}\text { Construction } \\
\text { of processing } \\
\text { facilities }\end{array}$ & tepend on current & required & not required (as a rule) \\
\hline
\end{tabular}

The most complicated direction is complex use of novel deposits (greenfield stage) as search works and the construction of processing facilities are need to be provided. Integrated exploitation of technogenic objects is one of the most prospective direction as mining wastes might be a source of rare- and rare-earth metals $[9,25]$.

However, despite the great resource opportunities, in comparison to other countries, the CUMR index in Russia is low as it is only about $40 \%$ for main types of mineral raw materials. For rare-earth metals this indicator reaches just under $20 \%$. As a result, an acute shortage of critically and strategically important types of materials has been formed. Especially, this is the case for rare and rare-earth elements.

The interests of the State and subsoil users within complex use of mineral raw materials are different. The State is oriented towards expanding production of critically important types of resources, reproduction of the resource potential, rational use of mineral and raw material base, long-term sustainable development, etc. By contrast, subsoil users focus mostly on profitability and cost-effectiveness of their businesses to achieve competitive advantages and to decline possible risks. Thus, there is a gap between interests of the State and subsoil users that should be eliminated through the adjustment of existing economic and managerial frameworks.

\subsection{Economic and organizational matters}

Both organizational and economic aspects influence the CUMR direction's development. The critical analysis of the managerial mechanism has shown some «gaps» preventing the effective use of the resource potential. First of all, - a declarative character of legal and regulatory documents should be mentioned. The majority of legal documents contains a regulation to implement «rational use of resources» [28]. However, the very term «complex use of mineral resources» is not established. This leads to the differing interpretations of the CUMR. 
The obligation of subsoil users to develop multicomponent ores on the basis of the CUMR principles is established (article 23 of the Law of the Russian Federation "On Subsoil"). Nevertheless, not all mining projects meet this requirement. In 2017, 1131 violations were identified, 92 of which were violations related to the protection of subsoil, 38 - irrational use of subsoil, selective (selective) development of areas of the field [34].

The existing mechanism for the rights distribution to use subsoil plots also does not create the incentives to ensure the complex development of multicomponent deposits (Nikitina 2018). The rights are granted to subsoil users on the basis of an adversarial procedure - auctions and competitions. The main difference between these two forms is the criteria for determining the "winner" (future subsoil user). During the competitive procedure, the winner is determined based on the proposed scientific, ecological and technical level of programs for the use of subsoil areas, indicators of completeness and degree of valuable components extraction, etc. In the case of an auction, the winner is the one who offer the largest amount of the starting payment. At the same time, the share of auctions in the total amount of procedures for the right to use subsoil plots reaches $94-96 \%$, competitions - only $3.9 \%[28,34]$.

Within the framework of auction procedures, there is also a problem of imperfect methodology for calculating one-time payments. Their size is often considered to be overestimated. This is one of the reason for the low investment attractiveness of a number of complex deposits (for example, the Seligdarskoye field).

One of the key problems related to the CUMR development is also the existing conditions of licenses for geological exploration and production of minerals. According to these, it is impossible to change initially approved range of extracted elements. Thus, the expansion of mineral raw materials list produced is basically forbidden that forms certain organizational barriers [34].

In general, identified organizational problems related to the CUMR direction in Russia can be listed as follows:

- Declarative character of the regulatory framework for the CUMR direction in Russia

- Imperfection of the mechanisms for the formation of the reserve fund of mineral resources (Decree of the Government of the Russian Federation No. 552)

- Uncertainty in establishing one-time payments

- Prevalence of the auction form of granting the right to use subsoil blocks

- Restrictions in the sphere of granting the right to subsoil users regarding amendments to the license within deciding on the extraction of associated components

- The lack of issues elaboration connected with the legal regulation of the technogenic deposits' development, general grounds for issuing licenses

Amendments of the existing managerial frameworks must be realized towards removing the current barriers and creating appropriate conditions for subsoil users to develop this direction. Economic mechanisms are also the subject of particular interest. From an economic point of view the CUMR projects are supposed to be comprehensive and highrisky because of the following features [22]:

- Poor quality of associated components in complex ores

- High level of knowledge and capital intensity of technologies for extraction of valuable components

- Uncertainty in establishing real market needs for individual components of mineral raw materials

- Difficulties in justifying and implementing a business diversification strategy

- Low profitability of associated valuable components' extraction (especially rare and rare-earth metals)

Obviously, the extraction of associated components may not always be effective in terms of financial and economic efficiency. The development of unconventional types of 
rare earth deposits using innovative processing technologies requires the construction of unique integrated complexes, that leads to significant capital costs even at the first stages of project implementation. The difficulties subsoil users might encounter include long-term R\&D stage, complex schemes for attracting financial resources, a shortage of information support in terms of planning and forecasting the development of individual markets for mineral resources, etc. The CUMR projects are often supposed to be ineffective because of a long pay-back periods, low level of key economic indicators, etc.

According to the "Strategy of development of mineral resources base of the Russian Federation till 2035" the economic incentive model is planned to use to enhance rational exploitation of the resource base. However, there are no special economic mechanisms to support the projects of complex use of mineral raw materials taking into account their specifics. The investigation has shown the possibility of available support measures' application. They include Development Institutions (Skolkovo, Russian scientific Fund, Venture Company, et al.) and schemes within Regional Investment Project, Special Investment Contract, Advanced Development Territories.

The usage of the support mechanisms discussed was based on the evaluation of the "Afrikandskiy" project economic effectiveness. The basic data for the calculations was presented by the Kola Science Centre Russian Academy of Science within formation of the Integrated chemical and metallurgical complex for the production of titanium dioxide, rare and rare earth metals (Integrated chemical and metallurgical complex for the production of titanium dioxide, rare and rare earth metals. Afrikandskiy project 2016). The baseline scenario was calculated without application of any support measures. Table 2 shows the results of comparative analysis of applied measures.

Table 2.The results of comparative analysis of applied measures (Afrikandskiy project).

\begin{tabular}{|c|c|c|c|c|c|c|c|}
\hline \multirow[b]{2}{*}{ Indicator } & \multirow[b]{2}{*}{$\begin{array}{l}\text { Baseline } \\
\text { scenario }\end{array}$} & \multicolumn{2}{|c|}{$\begin{array}{c}\text { Regional } \\
\text { investment project }\end{array}$} & \multicolumn{2}{|c|}{$\begin{array}{c}\text { Advanced } \\
\text { Development } \\
\text { Territories }\end{array}$} & \multicolumn{2}{|c|}{$\begin{array}{l}\text { Special investment } \\
\text { contract }\end{array}$} \\
\hline & & $\begin{array}{l}\text { Value of } \\
\text { indicator, } \\
\text { mln rub }\end{array}$ & $\begin{array}{c}\text { Deviation } \\
\text { from } \\
\text { baseline } \\
\text { scenario, } \\
\%\end{array}$ & $\begin{array}{l}\text { Value of } \\
\text { indicator, } \\
\text { mln rub }\end{array}$ & $\begin{array}{c}\text { Deviation } \\
\text { from } \\
\text { baseline } \\
\text { scenario, } \\
\%\end{array}$ & $\begin{array}{l}\text { Value of } \\
\text { indicator, } \\
\text { mln rub }\end{array}$ & $\begin{array}{c}\text { Deviation } \\
\text { from } \\
\text { baseline } \\
\text { scenario, } \\
\%\end{array}$ \\
\hline $\begin{array}{l}\text { NPV, mln } \\
\text { rub }\end{array}$ & -1783.95 & 183.01 & - & 2771.53 & - & -64.32 & - \\
\hline IRR, \% & 11.36 & 12.62 & 11.06 & 14.27 & 25.61 & 12.46 & 9.64 \\
\hline PI & 0.91 & 1.01 & 11.27 & 1.14 & 26.09 & 1.00 & 9.85 \\
\hline PP, years & $\begin{array}{l}\text { doesn't } \\
\text { pay off }\end{array}$ & 24 years & - & 16 years & - & $\begin{array}{l}\text { doesn't } \\
\text { pay off }\end{array}$ & - \\
\hline $\begin{array}{l}\text { Budget } \\
\text { efficiency, } \\
\text { mln rub }\end{array}$ & 16973.37 & 15006.41 & -11.59 & 12453.85 & -26.63 & 15253.73 & -10.13 \\
\hline
\end{tabular}

According to the obtained results, the greatest effect for subsoil users is formed due to use support measures within the framework of the tax-legal regime of Advanced Development Territories (NPV=2771.53 mln rubles, payback period -16 years). Regional investment project support measures also have a positive impact on the final financial results of the project, thereby increasing its commercial efficiency and the investment attractiveness. Therefore, these mechanisms might be applied to the projects' of complex use of mineral raw materials support as they may influence the investment attractiveness of such projects. 
In general, the critical analysis shows that current managerial and economic frameworks are imperfect and need to be reviewed. Novel incentives should be realized in order to attract both the State and the subsoil users to the problems of rational use of the resource potential.

\subsection{The concept of economic and organizational mechanism}

The organizational and economic mechanism means a set of functional processes and sequential connections between them, the functioning of which ensures the planned development of the integrated use of mineral raw materials as an independent direction within the environmental management.

The objects of the mechanism are multicomponent deposits and technogenic objects, the integrated exploitation of which is technologically possible and may be of strategic importance. The formation of a mechanism mentioned for the development of the CUMR should be focused on the implementation of the following long-term target priorities:

1. Providing the domestic industrial complexes with strategically and critically important types of mineral raw materials (including rare- and rare-earth elements). base.

2. Ensuring dynamic growth rates of indicators of reproduction of the mineral resource

3. Reducing the impact of environmental risks.

4. Intensification of geological exploration.

5. Ensuring the rational use of the resource potential.

The main idea of the mechanism offered is to combine both managerial and economic frameworks. Figure 1 shows foundations of the offered mechanisms.

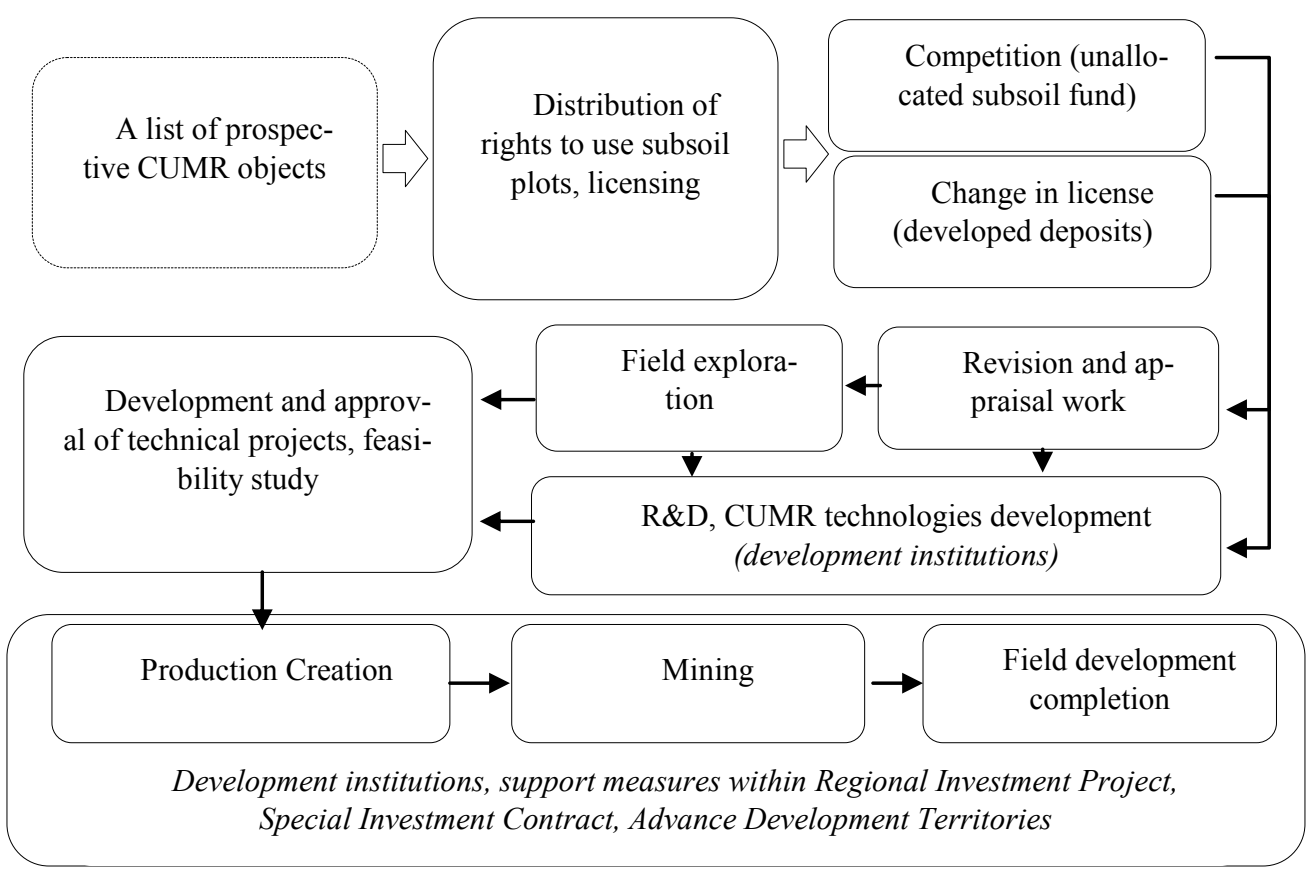

Fig. 1. Foundations of the mechanism offered.

At the first stage it is necessary to systemize all objects that might be prospective in the direction mentioned. It has been determined that there are three main directions to follow. 
Particular attention should be paid to the technogenic deposits as some of them are not belonging to the certain enterprises. That is why in certain cases not only economic, but also additional geological assessment must be provided to clarify the mineralogical conditions.

The conditions at the licensing stage also need to be reviewed. It is more preferable to distribute rights to use subsoil on a competitive basis. This measure may form further incentives for the subsoil users to enhance their ecological programs and technological schemes. This also applies to the technogenic objects. One of the important measures at this stage is to expand the list of companies eligible to amend existing licenses in accordance with the Federal Law of 03.07.2016 "On Subsoil" in order to obtain the possibility of extracting not taken into account earlier associated valuable components.

At the stages of deposits' exploration, revision and appraisal works, it is proposed to ensure the possibility of involving financial and non-financial development institutions, inclusion of projects in various tax and legal regimes. As it was mentioned before the processing technologies are usually very complicated to create and to introduce. That is why at these stages there is a need to attract additional financial resources to support subsoil users. It has been shown that not only the development institutions but also different tax and legal regimes might be involved in this process to improve the efficiency of the CUMR projects' implementation.

Figure 2 summarizes the main recommendations offered to the CUMR direction development in Russia.

\begin{tabular}{|c|c|c|c|c|}
\hline 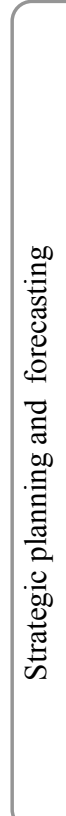 & $\begin{array}{l}\text { Improving the strategic } \\
\text { forecasting system } \\
\text { Implementation of } \\
\text { geological, preliminary } \\
\text { technical and } \\
\text { economic assessment } \\
\text { of complex deposits } \\
\text { based on a single } \\
\text { methodology } \\
\text { Formation of the } \\
\text { CUMR development } \\
\text { strategy (fixing special } \\
\text { measures to support } \\
\text { the implementation of } \\
\text { the CUMR projects } \\
\text { and clarifying the } \\
\text { conditions for their } \\
\text { implementation, } \\
\text { assuming of } \\
\text { differentiation the of } \\
\text { support measures } \\
\text { depending on the } \\
\text { specifics of individual } \\
\text { projects) }\end{array}$ & 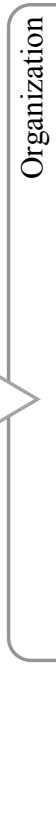 & $\begin{array}{l}\text { Distribution of rights to } \\
\text { use subsoil on a } \\
\text { competitive basis } \\
\text { Expanding the list of } \\
\text { companies eligible to } \\
\text { amend existing licenses in } \\
\text { accordance with the } \\
\text { Federal Law of } \\
03.07 .2016 \text { "On Subsoil" } \\
\text { in order to obtain the } \\
\text { possibility of extracting } \\
\text { not taken into account } \\
\text { earlier associated valuable } \\
\text { components } \\
\text { Involvement of } \\
\text { development institutions } \\
\text { and governmental } \\
\text { mechanisms to support } \\
\text { the CUMR projects } \\
\text { implementation }\end{array}$ & 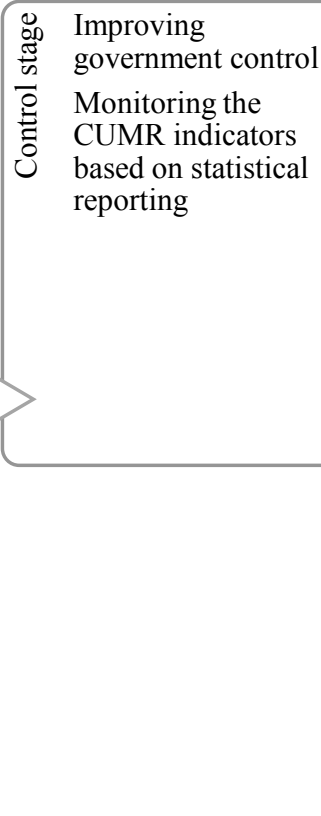 \\
\hline
\end{tabular}

Fig. 2. Recommendations aimed to the CUMR development

In general, recommendations for the formation of an organizational and managerial mechanism for the development of the integrated use of mineral raw materials have been developed on the basis of a critical analysis of the regulation and development of complex deposits features, an economic assessment of the possibility of implementing the CUMR projects. 


\section{Discussion}

The findings of this study suggest that the complex use of mineral raw materials is significant direction for Russia. It has been presented that the CUMR index in Russia is low. The preferable strategy for national subsoil users remains the excessive resource exploitation (selective mining) - the most effective from an economic point of view. This study has shown that the existing frameworks not only do not form the incentives to rational use of mineral resources, but also create the barriers for subsoil users. For example, it is forbidden to change a number of mineral elements mined. Thus, national subsoil users do not have opportunities to enhance the level of complex use of mineral resources even in the presence of economic and technological ensurance. The key problems of the CUMR direction have been systemized taking into account specifics of the current legal regulations and features of projects discussed.

The main idea of this study is to improve existing system due to the combination of both organizational and economic frameworks. Obviously, it is essential not only to provide financial resources, but also to create effective organizational mechanisms and to determine interaction forms between private and public partners.

The economic frameworks offered to support the CUMR projects' implementation are related to the governmental instruments. This stresses out the importance of the State participating within the issues connected with rational use of mineral resource base as the interests of the State are more global in this case. The findings of this study have a number of important implications for future practice.

\section{Conclusion}

To sum up, complex use of mineral raw materials is one of the most important directions within the efficient development of the national resource potential. In view of the raw materials orientation of the Russian economy, this topic becomes especially relevant in the context of depletion of domestic reserves of mineral raw materials, a decrease in the rate of reproduction of the mineral resource base, an increase in the degree of the formed deficit for a number of the most important types of mineral raw materials and an increase in environmental risks. To overcome these difficulties related to the extensive exploitation of mineral base it is necessary to follow the CUMR principals.

The existing subsurface management system is not perfect due to the lack of the issues elaboration related to the development of multicomponent ores, the granting of licenses for the right to use subsoil plots, etc. It has been found that in order to activate the CUMR process, it is necessary to remove a lack of interest among subsoil users in the implementation of the CUMR projects. As part of this, modern state mechanisms for supporting the development of such projects were investigated.

On the basis of the study, the mechanism for the development of the complex use of mineral raw materials as an independent direction has been proposed. It has been found that for the implementation of the CUMR direction, there is a need to combine not only organizational and legal mechanisms, but also justified the need to involve potential government measures of economic support in order to involve subsoil users in solving the problems of the complex use of mineral raw materials.

The mechanism offered in this research will allow to increase the efficiency of the CUMR projects' implementation from the economic point of view. Long-term effects will be connected with the ensurance of the national industrial complex in rare-earth elements and the dissemination of "green economy principals" in Russia. 
The research was carried out with the financial support of the Russian Science Foundation, the project "Strategic forecasting of development of industrial and mineral resources centers in the Arctic" No. 19-78-00108.

\section{References}

1. J. ScanlonThe Green Economy and International Environmental Governance.UNEP, (2009)

2. E.B. Barbier The policy challenges for green economy and sustainable economic development.Natural Resources Forum,35, 233-245(2011)

3. J. Reilyy Green growth and the efficient use of natural resources.Energy Economics,34, 585-593(2012)

4. C.F. BaileyMaking sense of the green economy.Geografiska Annaler: Series B, Human Geography,96, 195-200 (2014)

5. E.D.Brown, B.K. Williams Resilience and Resource Management.Environmental Management,56, 1416-1427(2015)

6. L. Georgeson, M.A. Maslin, M. Poessinouw The global green economy: a review of concepts, definitions, measurement methodologies and their interactions.Geo Geography and Environment,4(1), e00036 (2017)

7. E.I. Panfilov On the concept of rational, integrated development of georesources and conservation of mineral resources.Mining Industry, 1, 34-38(2006)

8. D.R.Kaplunov, D.N. Radchenko Substantiation of the full cycle of integrated development of subsoil in the development of deposits of solid minerals.Mining information and analytical bulletin (scientific and technical journal), S1, 447455(2011)

9. F.D. Larichkin Evolution and formation of the modern paradigm (model) complex use of mineral raw materials.Herald of the Kola Science Centre of the Russian Academy of Sciences, 4(11), 8-14(2011)

10. A. Tsvetkova, E. Katysheva Ecological and economic efficiency evaluation of sustainable use of mineral raw materials in modern conditions International Multidisciplinary Scientific GeoConference Surveying Geology and Mining Ecology Management, SGEM,17(53), 259-266 (2017)

11. T.V. Ponomarenko, M.A. Nevskaya, O.A. Marinina Complex use of mineral resources as a factor of the competitiveness of mining companies under the conditions of the global economy.International Journal of Mechanical Engineering and Technology,9, 1215-1223 (2018)

12. A.O. Nedosekin, E.I. Rejshahrit, A.N. Kozlovskij Strategic Approach to Assessing Economic Sustainability Objects of Mineral Resources Sector of Russia.Journal of Mining Institute, 237, 354-360 (2019)

13. K.N.Trubetskoy, Y.P. Galchenko, G.V. Kalabin, A.N. Poshlyakov Geotechnological paradigm of development of integrated mineral resources development in the Arctic zone of Russia.Arctic: ecology and economy,3(19), 54-65(2015)

14. F.D. Larichkin Mineral Resources in the Russian Economy.Journal of Mining Institute, 179, 9-13 (2008)

15. A.N. Vinogradov, Y.G. Glushchenko Mineral and Raw Material Potential of the NorthWest and Problems of its Rational Use.Journal of Mining Institute, 191, 107-112(2011)

16. A.A. Kozlov, V.A. Zukerman Innovative development of industrial enterprises of the mineral and raw materials complex of Russia. Bulletin of KSU,4, 35-37(2013)

17. A.N. Vukolov Problems and prospects of the use of technogenic mineral raw materials. International research journal,6(48), 130-131 (2016) 
18. M.A. Nevskaya Environmental and Business Challenges Presented by Mining and Mineral Processing Waste in the Russian Federation. Minerals, 9, 445 (2019)

19. A.Tsvetkova, E. Katysheva Present problems of mineral and raw materials resources replenishment in Russia. International Multidisciplinary Scientific Geo Conference Surveying Geology and Mining Ecology Management. SGEM,19(5.3), 573-578(2019)

20. A.A. Tverdov, A.V. Zhura, M.A. Sokolova Problems of the integrated use of mineral resources and the development of technogenic deposits. Rational development of mineral resources, 5, 16-20 (2013)

21. T.V. Ponomarenko, E.A. Khan-Tsai, Bavuu Chantsalma Integrated mining projects in underdeveloped territories of Russia: substantiation of implementation parameters.Journal of Mining institute, 240, 724-730 (2019)

22. O.A. Marinina, Y.N. Vasiliev Economic efficacy estimate of minerals multiple use for the purpose of efficient nature management.Journal of Mining Institute, 184, 235239(2009)

23. N.N. Yashalova Organization of stimulation of investment environmental protection activities in the region.Regional Economics: Theory and Practice,37(220), 6667(2011)

24. N.Y. Lobanov, V.A. Noskov Economic efficiency of complex use of mineral deposits.Journal of Mining Institute, 201, 59-63 (2013)

25. A.R. Mirzoyeva Evaluation of the economic efficiency of the integrated use of raw materials. Economic analysis: theory and practice,3(336), 51-60(2013)

26. V.M. Solovyova, A.E. Cherepovitsyn CUMR projects: Possibilities for implementation on Arctic territories.Topical Issues of Rational Use of Natural Resources 2019,(2019)

27. E.A. Solovyova Methodical foundations and principles for the formation of incentive taxation for subsoil use.Journal of Mining Institute,179, 14-19 (2008)

28. E.V. Tanin Legal regulation of study and development of complex (multicomponent) mineral deposits. Problems and prospects Journal of Mining Institute,201, 115119(2013)

29. D. L. Nikishin Main changes in the legislation on subsoil use in 20172018.Rosgeolekspertiza,2(4), 1-22 (2019)

30. A.A. Yalbulganov Legal regime of payments for the use of subsoil and ensuring the fiscal interests of the Russian State Law.Journal of the Higher School of Economics,3, 50-73 (2017)

31. M.A. Nevskaya, D.N. Ligotsky Organizational and economic problems of rational subsoil use and ways to solve them in modern conditions.Journal of Mining Institute, 201, 51-60 (2013)

32. Guidebook to the Green Economy Issue 2: exploring green economy principles.United Nations Division for Sustainable Development, UNDESA.

33. Working towards a Balanced and Inclusive Green Economy: A United Nations System-wide Perspective.Environment Management Group.

34. N.K. NikitinaRegulation of subsoil use in modern Russia: monograph. Gornaya Kniga,426,(Moscow,2018) 